\title{
Individual Ages in Manzoni's Conception of History
}

In any theory of history as progress it is difficult not to conceive of each individual age or generation as a mere instrument or stepping stone in itself. There is also a tendency to consider only those elements in an age that contributed to progress and consequently to neglect the conditions, both material and spiritual, of the human beings who lived out their lives therein. On the other hand, the melancholy or despair engendered by the inevitable passage of time and by the transience of all things in an endless sequence of generations has found consolation in religion, whether through worship of ancestors in an unchanging primitive society or through a transcendental god in an eternity into which men would pass after death. Homer could compare the generation of men to that of leaves: both die, but another generation of each is born. ${ }^{1}$ Later writers, however, contrasted the constant rebirth of nature with the final death of the individual. In modern times, as J. $\mathrm{H}$. Plumb has pointed out, ${ }^{2}$ the growth of technological change has meant that work skills and patterns can no longer be learned at home from one generation to the next: the links between generations have been loosened, since only the present can have the validity, the hold of the past has weakened and thus also, we might suggest, the interest in past ages. More recently, the uncertainty and constant change in the present have perhaps contributed to a renewed interest in the past, whether in a quest for roots or in a desire to investigate human emotions and problems, as exemplified in historical novels or romanticized biographies - a return, in part, to the Romantic position of the earlier nineteenth century.

In the second part of his Discorso sopra alcuni punti della storia longobardica in Italia, ${ }^{3}$ Manzoni identifies the originality of Giambattista Vico's contribution to historical interpretation, while lamenting:

E seguendo il Vico nelle ardite e troppo spesso ipotetiche sue classificazioni, come si vorrebbe andar sempre avanti con la guida di fatti sufficienti all'assunto, e severamente discussi! (p.43) 
Manzoni had just previously commended Muratori for his concentration on facts but had speculated on the great effect which would be produced by a union of his method with that of Vico. For the latter, history represents human progress, the perpetual creation by man of himself and his world, the realization of his potentialities, in an ordered development as Providence operates through man's own capacities. For Vico, however, unlike some Enlightenment thinkers, each age is of value and its individual characteristics can be identified and understood by subsequent generations through the imagination, the fantasia, which generates our sense of the past, no matter how different its culture, thought, patterns and means of expression may be, governed, as they were, by its distinctive historical context. Human nature is not unchanging but is in constant development. ${ }^{4}$

The men of the Enlightenment tended to look at past ages from their own assured rational viewpoint, which they considered as final and absolute. In history, they sought the struggle of reason against the forces hindering its progress. It was generally held that not all ages could be justified as equally necessary in the course of human progress. The eighteenth century was obviously the highest point yet reached, not least because its thinkers were aware of the power of reason and its role in history and through this awareness, were in a position to accelerate its advance to an eventual state of social peace and happiness. The formulation of a precise doctrine of progress followed naturally and reached its height in Condorcet, who traced the continuous progress of the human race up to the coming tenth epoch. Unlike Vico, David Hume considered the principles of human nature to be constant and universal and the purpose of historiography is to illustrate and clarify them. ${ }^{5}$ Since reason and natural order are always the same, added Turgot, the historian should strip away the accidents of period and place in order to reveal the universal principles of human nature: each historical age is inseparably linked to its predecessors by an unbreakable chain of cause and effect. ${ }^{6}$

In other ways, however, some philosophical historians of the Enlightenment expressed viewpoints which are usually considered typical of the Romantics. Though Montesquieu expected that the advancement of knowledge would bring a new moral order and a new orientation of the political and social history of man, he could also say that carrying over into remote centuries all the ideas of the century in which we live is one of the most fertile sources of error, a point echoed by Manzoni in the Discorso sopra alcuni punti della storia longobardica in Italia: "Queste poche parole d'uno scrittore sí diligente e sí sagace, possono servire per un esempio insigne 
di quel costume tanto comune a molti storici di pigliare le convenzioni moderne per misura a giudicare i fatti accaduti in tempi, in cui queste convenzioni non si sognavano nemmeno," where the writer in question is Muratori. Montesquieu also anticipated a typical Romantic outlook in his statement that, when he came to speak of ancient history, he tried to assume the spirit of antiquity and to become an ancient himself. ${ }^{8}$ In his Essai sur les Moeurs et l'Esprit des Nations, Voltaire said that he would have liked to know the kind of family in existence in a given age, how people lived within their families and what arts were practised - an interest, that is, not in general history, but in the individual, a need later echoed by Condorcet. ${ }^{10}$ Voltaire also asserted that only those who have written tragedies can cast some interest into history since they know how to paint and arouse passions: from his composition of plays derived his method of writing history, this method "d'encadrer et d'isoler chaque partie de l'histoire générale" being identical with the procedure of a playwright "qui encadre un fait historique pour en composer une tragédie." 11 The metaphor of painting was frequent among historical novelists of the early nineteenth century, including Manzoni, as was the use of the concept of "spettacolo" for the individual scenes of a novel.

In Germany, Herder maintained that each historical age and each people, as well as each age of the individual, has its centre of happiness in itself and we must not judge earlier people or their ethics by the standards of other times; every human achievement is conditioned by the time and place and by the circumstances and stream of conditions that press in upon people involved in a situation. Happiness, which is the goal of human life, can be realized in each stage of human history, since it is an inner condition of the human mind and spirit. Nature created a vast variety of forms of human existence so as to bestow upon each man the appropriate measure of satisfaction in his time and situation. Herder called on historians to "enter into the age, into the region, into the whole of history, feel yourself into everything. ${ }^{\prime \prime 2} \mathrm{He}$ also wrote "Nothing in the whole kingdom of God is ... a means only ...everything is means and end at the same time, and certainly also these centuries. ${ }^{\prime 13}$ Pietro Verri had asked whether it was right and reasonable to hazard the repose and safety of a living generation, which has a present right to a good existence, for the uncertain hope of obtaining tranquillity for generations still to be born, and the abate Ferdinando Galiani asserted: "Il ne doit être question que du bonheur des êtres réels, des individus existants ou prévus. Nous et nos enfants, voilà tout. Le rest est rêvérie."14 Justus 
von Möser spoke of the need for an "Einleben und Einfühlen in die Dinge."

In his youth, Manzoni accepted the eighteenth century and Jacobin confidence in the establishment of peace and justice, as we see in the poem Il Trionfo della Libertà of 1801, where he contemplates history in general terms as something "astratta e mitizzata secondo i modelli del razionalismo," ${ }^{16}$ identifying obstacles which have impeded the development of liberty. His disillusionment with the actual conditions in the Cisalpine Republic ${ }^{17}$ caused Manzoni to stand outside society in various poems in the following years - Alla sua donna, Frammento di un'ode alle Muse and the Sermoni - and to style himself the "giusto solitario" in the carme In morte di Carlo Imbonati, who could thus maintain his own purity and the lofty mission of his poetry. The conversion of 1810 not only provided a basis for his moral feeling but also led him to contemplate the position of the individual as such and then his place in society which, as a historical phenomenon, partook of the "vero" which we can find only in history. If the "vero storico," coupled with the "vero morale" was the only subject worthy of our attention, it followed that every manifestation of the "vero" was interesting and that no age or generation could be neglected, an idea which was later to be confirmed for Manzoni by the theory and practice of French Romantic historians.

The Inni Sacri, rather than the tragedies, mark Manzoni's first excursion into history. He describes, even narrates, the events of Christ's life in a past historical age, but, since these events were both temporal and eternal as reflecting the dual nature of Christ on earth, he shows the link between temporal and eternal at each moment and in each age through the power of Church ritual to renew these events and their enduring significance. In the religious sense, therefore, every moment and every age was of equal value and this value derived, not from any role in historical process, but vertically from the eternal. In a letter to Auguste Stolberg of 17 April 1823, Goethe spoke of the eternal present in every moment and remarked to Eckermann on 3 November 1823 that every situation indeed every moment is of enduring value since it is the representative of eternity. As Leopold von Ranke was to say, each generation stands equidistant from eternity and each is an end in itself, an idea carried on in this century by the eschatolgy of Karl Barth. The contrast with Hegel's position is quite clear: for him, history is a becoming, the development of the spirit in time: everything can only appear as it does and when it does it is merely instrumental since it is only a passing movement in our passage to the Absolute. 
Manzoni re-evokes the historical moments of Christ's life. As Ulivi remarks of La Pentecoste: "il Cristo che sale al cielo. . è un'evocazione'reale" and "è il romantico richiamo di un gran giorno, di un evento irrepetibile consumato per sempre," the sublime nostalgia for an hour relating to all humanity. ${ }^{18}$ In $I$ Promessi Sposi, Manzoni would deal with the state of a society in a given age, including each social class: an earnest of this is found in La Pentecoste, as Barberi Squarotti observes, "La rassegna totale dell'umanità si svolge sotto il segno della definitiva costrizione, che stabilisce l'esatta determinazione di ogni età, stato del sentimento, condizione economica, entro la visione della perfezione assoluta, equilibrata, in un esatto calcolo di misura regolata, dominata, negato a ogni eccesso, a ogni ventura, a ogni slancio. . . ."19 Manzoni contemplates the whole of society in any moment. It must be added, however, that, as in I Promessi Sposi, he penetrates to the life of the individual and to his moral responsibilities. ${ }^{20}$

The question at issue in the two tragedies is whether the two ages in which they are set are individualized or whether, beyond their purely contigent characteristics, they are simply representative of all ages or of constantly recurring ages in which injustice is predominant. The Inni Sacri had recalled a time and events that were unique. Again, are the principal characters universal types, or figures typical of nineteenth-century Romanticism, or historically determined while conveying a general statement about life? In his letter of 7 February 1820 to Gaetano Giudici regarding Il conte di Carmagnola, Manzoni speaks of a specific character and age and asks whether:

Un uomo di animo forte ed elevato e desideroso di grandi imprese, che si dibatte colla debolezza e colla perfidia de' suoi tempi, e con istituzioni misere, improvide, irragionevoli, ma astute e già fortificate dall'abitudine e dal rispetto, e dagli interessi di quelli che hanno l'iniziativa della forza, è egli un personaggio drammatico ${ }^{21}$

a well defined character, that is, living in any age with recognizable characteristics. Manzoni goes on to identify two types of interest experienced by the spectator of a drama: that which arises from our seeing men and things presented in conformity with that type of perfection and desire which we all have within us; and, secondly, the presentation of that mixture "di grande meschino, di ragionevole e di pazzo che si vede negli avvenimenti grandi e piccioli di questo mondo." He had used these two methods of generating emotion and reflection, one in the tragedy itself, the 
other in the chorus. It seems to me that Manzoni has not individualized a given age, in this case the fifteenth century in Italy, but has presented a general and recurring situation - the just man who falls victim to the inevitable injustice of political life, governed as it is by considerations of self-interest, a situation dear to the Romantics. A general characterization of the age is lacking and the comments of ordinary Venetians to Carmagnola's father which were included in the first version have been removed. Apart from the relationship between the temporal and the eternal - the latter a mere escape from and a negation of the former $-I l$ conte di Carmagnola is of interest for its investigation of the reaction of the individual to historical situations: "il poeta del sistema romantico shakesperiano è chiamato per l'appunto a ricostruire quell'uomo interiore che il passato lascia inabissare sotto gli eventi," as Ezio Raimondi puts it, ${ }^{22}$ but, in the case of Carmagnola himself, his thoughts relate in the end not to history or his age as such but to his own relationship with the eternal. The chorus, however, comments from a historical viewpoint on the evil of civil war, with its implied plea for united action by the Italians of Manzoni's own day.

Adelchi is at first the victim of a historical situation produced by the actions of his father, Desiderio, in threatening the territory of the Pope, but this situation is later generalized within a wider historical process. The peculiar characteristics of his age are never specified, nor are the motives and actions of Carlo, of Desiderio and of the rebellious Lombard nobles in any way limited to their age. Carlo ably takes advantage of Lombard disunity and of the Pope's call for assistance but he is the eternal Machiavellian politician who is in no way formed or conditioned by his age, though his precise actions are governed by historical circumstances, since he lacks any spiritual dimension. ${ }^{23}$ The chorus "Dagli atrii muscosi" makes it clear that the Frankish supplanting of the Lombards as masters of the subject Italians is part of a series, a historical action, but not possessed of special features. The series included, centuries later, the events of 1796 to $1821 .{ }^{24}$ Ulivi speaks of the "succedersi triste delle generazioni." 25

Ermengarda, too, is a victim, rejected by her husband Carlo for political reasons; but again, her position is not unique: "Altre infelici dormono,/Che il duol consunse. . ." The impression, says Sansone, "è il succedersi delle cose." ${ }^{26}$ She is less an individual in a historical sense than a person "dalla rea progenie/Degli oppressor discesa" and placed by "la provida sventura" among the oppressed. This same circumstance is later adduced by Adelchi (V.8) in his words to Desiderio: 
Una feroce

Forza il mondo possiede, e fa nomarsi

Dritto: la man degli avi insanguinata

Seminò l'ingiustizia; i padri l'hanno

Coltivata col sangue; e omai la terra

Altra messe non dà.

In the Adelchi there is one episode, a "hic et nunc scenico," to quote Lonardi, in which are foreshadowed similar situations and narrative devices in I Promessi Sposi. ${ }^{27}$ I refer to Martino's account of his journey across the mountains. The journey is recreated for the reader who almost accompanies Martino, through the frequent use of verbs of "seeing." ${ }^{\prime 28}$

The autonomy of "generations" emerges clearly in the Osservazioni sulla morale cattolica of 1819 , though the concept does not go beyond the moral or narrowly cultural, as is inevitable in this context. The Osservazioni deal essentially with the position of the individual in general with little regard for his place in specific historical situatious: it is the unvarying context of life and death, of time and relationship to the eternal. "Tutto ciò che non è preparazione alla vita futura, tutto ciò che ci può far dimenticare che siamo in cammino, tutto ciò che prendiamo per dimora stabile, è varietà ed errore." ${ }^{29}$ In I Promessi Sposi, such a position will be integrated into concrete history, precisely because of the essential importance of this life in determining our position in the next life: but the Osservazioni can be regarded as a necessary preliminary for the dramatization of moral questions in specific historical situations.

In the first chapter of the second part of the Osservazioni, Manzoni discusses the opposition between religion and the "spirito del secolo." "The spirit of the age," or of the time, was a favourite topic in that period. William Hazlitt's book entitled The Spirit of the Age, came out in 1825, but the topic is there treated rather differently. ${ }^{30}$ Manzoni is contrasting the unchanging position of the Church with the varying viewpoints held in succeeding ages or simply with a purely worldly position which cannot have any enduring value. The dominant ideas in a given age may degenerate into a "tirannia di opinione" (p.491). Each "secolo," says Manzoni in the ninth Fragment (p.563), has certain leading opinions which constitute its "spirit" and which, after the invention of printing, derive from a few thinkers of the previous generation since, when they are first put forward, these opinions are commonly either denied or completely neglected, an observation repeated in Pensiero $X V$. The truths to which they penetrated may be inevitable in that they would be discovered even by 
mediocre minds through the "progresso naturale delle cognizioni." Elsewhere (p.536), Manzoni states that "il tempo e il progresso dei lumi hanno distrutte istituzioni orribilmente ingiuste, ma che nello stesso tempo erano mezzi di conservare la società: tale è la schiavitù degli antichi" and "lo stesso progresso di lumi rendeva impossibile la durata delle assurde religioni esistenti" (p.537). In the Lettera sul romanticismo of 1823, he refers to the "progresso naturale delle scienze economiche." ${ }^{31}$ Nowhere, that is, does he deny the advance of knowledge and Reason (which he prefers to capitalize). A generation can be strongly convinced of the rightness of its thought and yet be mistaken: thus it is not surprising that the principles of religion are opposed to the spirit of such a generation. One age may proclaim a false principle and deplore the blindness of its ancestors in adhering to the opposite extreme and yet, while enumerating the circumstances that had produced such a gross error, fail to discern that similar circumstances have led to the opposite error and to its continuation. Manzoni identifies some basic ideas and institutions of certain ages which had been superseded, such as the spirit of chivalry, that is, the concept of "honour," and slavery. If someone in the "bei tempi" of the Romans had described war as cruel madness, how would he have been received? Would any reply have been deemed necessary to a contention that the helots had the same rights in regard to freedom and law as the Spartans themselves?

In 1819-20, Manzoni was in Paris where he came to know two historian friends of Fauriel - Augustin Thierry and François Guizot. In the Censeur Européen in 1817, Thierry had said that, despite the apparent changes in history, the lot of the people, of "les sujets," of the defeated, remained constant. In the same journal two years later, he affirmed that the conditions of the present are best understood by looking at the past, of which a "peinture vive et fidèle" is needed. Painting a picture of an age is synonymous with bringing it back to life and the term "colouring" signifies the animation of bare facts. Thierry repeats his interest in, and sympathy for, the humble who are the most numerous part of a nation and yet are forgotten. ${ }^{32}$ In the preface of 1834 to his Dix ans d'études historiques, he recalls his projected reform of around 1820 , declaring war "aux écrivains sans érudition qui n'ont pas su voir, et aux écrivains sans imagination qui n'ont pas su peindre." ${ }^{33}$. In Waverley, a novel well known to Manzoni, Scott says of the hero that he loved to fill up and round the sketch with the colouring of a warm and vivid imagination, which gives light and life to the actors and speakers in the drama of past ages. It was Thierry who spoke of the tragedy of the generations that had passed over the 
earth leaving no trace of themselves: "Il faut pénétrer jusqu'aux hommes, à travers l'espace des temps; il faut se les représenter vivant et agissant sur le sol où la poussière de leurs os ne se trouverait pas aujourd'hui." ${ }^{134}$ Finally, he believed, like Manzoni, that the novel can contain the truest part of history, essential for the recreation of an individual age.

The Lettre à $M$. Chauvet of early 1820 speaks not of the novel, but of dramatic poetry: "Expliquer ce que les hommes ont senti, voulu et souffert, par ce qu'ils ont fait, voilà la poésie dramatique." ${ }^{\prime 35}$ The essential point is the recovery of men's inner life, worked out from the events in a detached and self-contained portion of history: the poet fills out this portion of history and shows its moral effect. Although Manzoni uses the term "le caractère propre des hommes et de l'époque que je veux peindre" (p.373), he is less interested in the features of an individual age than in the psychological and spiritual life of its prominent figures as an index of general human life and for its salutary moral effect on the reader or spectator.

The Discorso sopra alcuni punti della storia longobardica in Italia, begun in autumn 1820 and published in 1822, is far closer in many respects to the position of Thierry. The concept of an individual epoch with its own characteristics is now fully accepted and stressed. History consists not of material and external facts nor are these sufficient to form the dramatic concept of a historical event:

Le circostanze di leggi, di consuetudini, di opinioni, in cui si sono trovati i personaggi operanti; le intenzioni e le tendenze loro; la giustizia, o l'ingiustizia di esse, indipendentemente dalle convenzioni umane, secondo o contra le quali è stato operato; i desiderj, i timori, i patimenti, lo stato generale dell'immenso numero d'uomini che non ebbero parte attiva negli avvenimenti, ma che ne provarono gli effetti. ${ }^{36}$

There is the usual Manzonian admixture of the historical and the moral which brought on him the condemnation of Croce. Yet Manzoni insists that subsequent generations must study earlier ones in themselves and not lose sight of their true character:

è questo un altro esempio di quel costume quasi generale presso i moderni di tirare le cose antiche alla misura dei loro tempi, e di toglier così ad esse ciò che hanno di più caratteristico e di più istruttivo. (p.223)

Similarly we think that men invested with power in history held it for a purpose that is for us "il solo ragionevole ed onesto" (p.297). It is a curious way of observing history:

di prendere per misura a giudicare una serie di fatti, gli interessi della posterità, e non quelli della generazione che ha subito quei fatti: come se 
alcuno potesse prevedere con qualche certezza lo stato che a lungo andare sarebbe risultato da fatti diversi. E, quando pur si potesse, non sarebbe tuttavia nè ragionevole nè umano il considerare una generazione puramente come un mezzo di quelle che le succedettero. (p.245)

A generation, like an individual man, lives its own autonomous life and cannot be a mere instrument of other generations, as though its people were in some way incomplete. Each generation will certainly benefit from the efforts of the past but must live by its own efforts and regard its inheritance as something to be expanded rather than lived upon in idleness.

Up to this point, Manzoni has concentrated upon the individual's feelings, thoughts and problems with some general statements on the intellectual climate of the age and references to the condition of the humble. Now, certainly using the example of Sir Walter Scott as his starting point, he carries the process much further. He described approvingly to Fauriel in a letter of 29 January 1821 Tommaso Grossi's intention in the narrative poem I Lombardi alla prima crociata: "Son intention est de peindre une époque par le moyen d'une fable de son invention, à-peu-près comme dans Ivanhoe." ${ }^{38}$ Manzoni refers to "ce système d' invention des faits pour développer des moeurs historiques." Grossi will gather together "les traits charactéristiques d'une époque de la société." Manzoni's point of arrival is seen in the famous letter to Fauriel of 3 November 1821, in which appears explicitly the idea of describing a past age in its total extent and depth. Manzoni says that he conceives of the historical novel as a representation of a given state of society by means of actions and characters so similar to reality that they could be considered a true history which had just been discovered. Clearly, "state of society" must include the conditions, both material and spiritual, of all social classes, including social attitudes. Manzoni told Fauriel on 29 May 1822 that he was doing what he could to penetrate himself with the spirit of the time in order to live in it and mentions arbitrary government, feudal and popular anarchy, astonishing legislation, profound ignorance, hostile classes and a plague in which were shown consummate crime, absurd prejudices and the most touching virtues. In August 1823, he wrote that he had tried to discover, know exactly and paint faithfully the age and the country in which he had placed his history. Though this must mean that he wishes to understand the viewpoints of the age, he will obviously not judge events and characters by such standards. It is interesting to note that, in the preface of his novel Julia Severa, the Swiss historian Sismondo de' Sismondi (Manzoni's adversary in the Osservazioni 
sulla morale cattolica) said that the historian is, as it were, obliged to live in the age he describes, but that such continued labour cannot be expected in the mere novelist; he wished in his novel to describe the ancient state of society such as it was, at least such as we must conceive it was, with all its virtues and vices. ${ }^{39}$

Scott, observes Karl Kroeber, made it possible to describe any society in its temporal dimensions, whereas, before him, social organization had remained static in novels. He presented society as the product of past experiences and traditions which are in the process of becoming something different. ${ }^{40}$ Thus his novels of the recent past - his first nine dealt with the 17 th or 18 th centuries make of this recent past a preparation for the present, though the past does not lose its intrinsic value. He chooses ages that mark a turning point, for example the supersession of Scottish chivalrous patriotism as represented by the Highlanders in the rebellion of 1745 in Waverley, Anglo-Saxon against Norman, Royalist against Puritan and so on, but establishes a dynamic relationship between characters and historical conditions and development. He tends to look at history through character and at character through the history that had worked upon it, ${ }^{41}$ while affirming that the passions are generally the same in all ranks and conditions, all countries and ages and that the opinions, habits of thinking and actions, however influenced by the peculiar state of society, must still, upon the whole, bear a strong resemblance to each other. ${ }^{42} \mathrm{He}$ establishes, however, the historical peculiarity of an age and its psychology and ways of thinking. The description of customs and ways of life of various classes are essential elements in the overall picture and should not be considered mere local colour. Scott's moderate attitudes and his feeling for ordinary life suppressed the tragic note in most of his novels and brought the reader from heroic ideals back to ordinary humanity. ${ }^{43}$

Fermo e Lucia realized Manzoni's ideal only in part and the frequent emphasis on the special characteristics of the early 17 th century in Lombardy as opposed to his own times are perhaps indicative of a realization that these characteristics had not been absorbed artistically into the story and into the representation of the characters and also of a failure to understand the age in itself. He refers to "quei tempi di funesta memoria" (p. 160); ${ }^{44}$ of Geltrude "le sue parole e il suo contegno sarebbero state uno scandalo insopportabile in un secolo meno bestiale di quello" (p.225); "perchè a quei tempi tante cagioni favorivano la scelleratezza, che in coloro i quali vi si distinguevano, ella giungeva ad un segno del quale grazie a Dio, non si può avere una idea dalla esperienza comune del vivere presente" (p.209); when Lucia was in Milan, 
"Agnese si rassegnava all'idea di esser lontana da sua figlia, come ai nostri giorni farebbe una madre della condizione di Agnese, che avesse una figlia collocata in Inghilterra" (p.509). At one point, Manzoni indulges in a lengthy discussion regarding different ideas in different times and generations, ideas which are held to be true. We may feel self-satisfaction when we look at the times described in the novel, but what will the future think of us? Certain ideas are dominant for one, two or more generations and a very curious history could be written about ideas that have reigned for a certain time and then fallen away (pp.560-64). Finally, Manzoni has a criticism of historians and an implicit statement of his own aims: of Padre Felice Casati, the head of the Capuchins in the lazzaretto, he says "Fra quel nobile volgo si distinse un uomo che avrebbe un nome storico, se la storia fosse consecrata a descrivere lo stato delle società nei diversi tempi, e a segnalare i fatti e i caratteri che più servono a far conoscere la natura umana" (p.568).

In I Promessi Sposi, Manzoni's treatment of the age differs from that of Scott. The latter presented an age that was dynamic rather than static, which included concrete individuals and historical forces and had its own human value but which was still part of a political and social process. As Bruno Stagnitto remarks, Manzoni brings back these individual historical actions to their immediately verifiable character, to their contemporary significance in individual or mass suffering: Stagnitto cites as an example Manzoni's observations on the siege of Casale..$^{45}$ Salvatorelli comments that the lot of a people at a given moment takes precedence over political and national criteria. ${ }^{46}$ Manzoni does not present a struggle between Italians and Spaniards, but conditions within a society and its reactions at various levels to external circumstances - famine, war, plague: a static picture or, at most, a moving picture within the confines of a definite frame. Yet this assessment is not complete if the final position of Renzo and Lucia is taken into account. It is true that the author attributes to them on the final page "il sugo della storia," which is a judgment of their adventures and misfortunes in regard to universal human life and to God and the next life, a judgement in harmony with the Christian moral tone to which individual actions have been related earlier; but, as various critics have pointed out, the couple's move from their village to Bergamo represents their progress from a feudal condition to an incipient capitalism with Renzo an employer of labour in a spinning mill, which is also indicative of the general movement from feudalism to capitalism. 
Lukács maintains that the absence of a world-historical atmosphere "manifests itself in Manzoni in a certain limitedness of human horizon on the part of his characters... Compared with the heroic drama of Scott's Jeanie Deans or Rebecca, the fate of Lucia is really no more than an externally menaced idyll, while an inevitable pettiness attaches, to the negative characters of the novel: their negativity is unable to reveal dialectically the historical limits of the whole period and therewith also the limits of the passive figures, as does, for example, that of the Knight Templar in Ivanhoe. ${ }^{\prime 47}$ In fact, a marriage between two contadini can scarcely be called an idyll. The external menace from Don Rodrigo exemplifies both the feudal system and its accompanying code of "honour" and their effect, while the reactions of Renzo and Lucia illustrate the limits inevitably imposed upon their class. The weakness of law enforcement when the powerful are involved is also shown, with creatures of the law such as Azzeccagarbugli conforming to the situation. The famine, the war and the plague bring out the incompetence of foreign rule based on the local aristocracy. There is, of course, no indication of any future change in the system and, in this sense, Lukács' criticism is correct - if an indication of future change is, in fact, inherent in every age at every time.

The turning point in the novel is the conversion of the Innominato, which was based upon a historical event. Since for Manzoni there are two kinds of "vero," the "vero storico" and "vero morale," both must inevitably enter his portrayal of a historical age; he thus tends to isolate the age, without a horizontal relationship in a historical sense, but with constant vertical reference to the eternal which lies behind every moment of human existence. While the father of Gertrude is totally enclosed within his time and his actions are explicable only in its terms, the Innominato must stand outside the age for a moment in order to return to it, repentant, and to live the rest of his life actively within it. Clearly, changes can be effected if enough persons in powerful positions undergo such a conversion, but Manzoni gives no other indication of change within that age.

After the estrangement from their age of Carmagnola and Adelchi, with the Romantic solution of death and tranquillity as the only escape, Manzoni has now realized that no escape is possible, that each man belongs to his age, must live his life and make decisions in that age and in those conditions. Don Abbondio with his system of neutrality sought to contract out of his age and thus of the only possible context of his life, and was bound to fail. ${ }^{48}$ In a far different sense, the Innominato's life acquired meaning for him only when he returned to the community. 
Manzoni had told Fauriel that he was endeavouring to penetrate the spirit of the time in order to live in it. It may be suggested that he went even further and imagined himself present at certain scenes. His technique of having a character walk through the streets during certain broader events or in a continuing situation is significant: his full consciousness of this technique is shown by his joking about it in Fermo e Lucia. Renzo enters Milan and advances through strange conditions before becoming involved in the food riots; the process is repeated during the plague, while an observer is implicitly present to see conditions engendered by the famine. On each occasion, the author intervenes to describe what his character saw - and the verb of seeing is used frequently. The same immediacy is evident in various other scenes such as the meeting of Don Abbondio and the bravi or between Borromeo and the Innominato: in these the author's close observation of gestures and expressions enhances the effect. Manzoni termed some of his scenes "ritratti" and "spettacoli." It is hardly surprising that a number of scenes from the novel, as with the Waverley novels of Scott - who felt that a pictorial or scenic quality was essential at moments of intensity in the action of the novel ${ }^{49}$ - became the subjects of painters and illustrators.

In the last analysis, for Manzoni every age is of equal importance because it is composed of human beings who are equal before God. ${ }^{50}$ History, composed of ages or generations, can be compared with the autonomous moments, each of equal value, of the individual human life.

\section{University of Toronto}

\section{NOTES}

1 lliad VI, $147 \mathrm{ff}$.

2 The Death of the Past (Harmondsworth, 1973), pp.48-49.

3 In Tutte le opere, a cura di Alberto Chiari e Fausto Ghisalberti, IV (Milano, 1963), 40-43

$4 \mathrm{Cf}$. Isaiah Berlin, Vico and Herder. Two Studies th the History of Ideas (London, 1976), pp.34 ff. and 112 .

5 Ralph G. Wilburn, The Historical Shape of Faith (Philadelphia, 1966), p.58.

6 Ocurres, ed. Gustave Schelle (Paris, 1913), I, 277; see also Frank E. Manuel, Shapes of Philosophical History (Stanford, 1965), p.98 ff. For the typical position of Italian historians of the Enlightenment, see Nicola Abbagnano, "1l concetto della storia nell'illuminismo italiano," Rivista di filosofia, 56 (1965), 291.

7 See Ernst Cassirer, The Philosophy of the Enlightenment, trans. Fritz L. A. Koelln and James P. Pettegrove (Boston, 1955), p.214

8 De l'Esprit des Lois, Livre XXX, ch. XIV (Paris, 1949), II, 314 and Cassirer, p.215. For the quotation from the Discorso, see Tutte le opere, IV, 187. Bettinelli had stated "Dunque chi vuol giustamente sentenziar Dante si dee trasportare in Toscana e in Italia tra le turbolenze e l'ignoranza di quei giorni." See the eighth 
of his Lettere inglesi in Lettere virgiliane, Lettere inglesi e Mia vita letteraria, a cura di Gilberto Finzi (Milano, 1962), p.166.

9 Quoted by Sidney Pollard, The ldea of Progress. History and Society (Harmondsworth, 1971), p.34.

10 Sketch for a Historical Picture of the Human Mind, trans. June Barraclough (London, 1955), p. 170.

11 See the Introduction by René Pomeau, p. lxiii, to Essai sur les Mocurs (Paris, 1963).

12 Roy Pascal, The German Sturm und Drang (Manchester, 1953), p.226; Robert T. Clark, Jr. Herder: His Life and Thought (Berkeley and Los Angeles, 1969), pp.191, 194, et passim; René Wellek, The Later Eighteenth Century, Vol. I of A History of Modern Criticism (New Haven and London, 1955), p. 185.

13 See Wellek, p.185. The passage is quoted from Auch cine Philosophie der Geschichte zur Bildung der Menscheit (1774). Kant criticized Herder for this position in his Idee zu einer allgeneinen Geschicht in weltbürgerlicher Absicht of 1784.

14 For Verri, see Luigi Salvatorelli, Il pensiero politico italiano dal 1700 al 1870, 4th ed. (Torino, 1943), p.62, n.1; for Galiani, see F. Nicolini, Il pensiero politico dell'abate Galiani (Bari, 1909), p.151: this passage is also quoted by Augusto Simonini, L'ideologia di Alessandro Manzoni (Ravenna, 1978), p.112, n.16.

15 See Pollard, p.39.

16 Ferruccio Ulivi, 11 Manzoni lirico e la poctica del Rinnovamento (Roma, 1950), p.66; cf. Pietro Mazzamuto, Poetica e stile in Alessandro Manzoni (Firenze, 1957), p.210.

17 He refers to "le spectacle affreux de la corruption de mon pays" in a letter to Claude Fauriel of 19 March 1807: see Lettere, a cura di Cesare Arieti, Volume VII, Tomo l of Tutte le opere (Milano, 1970), p.34

18 Op. cit., p.125. Filippo Piemontese commented: "Poesia storica è dunque sostanzialmente la poesia degli Inni Sacri," in Studi sul Manzoni e altri saggi (Milano, 1952), p.39.

19 Teoria e prove dello stile del Manzoni (Milano, 1965), p.45. In La Passione, Ulivi, p.61, sees "un più diffuso tessuto narrativo. Da qui si può prevedere ormai non lungo il cammino al pathos della vita quotidiana e della situazione storica." Goffis finds that the real novelty of these experiments in the sacred lyric lies in the indication of "la possibilità di un tono narrativo," in La lirica di Alessandro Manzoni (Firenze, 1964), p.146.

20 Cf. Ezio Raimondi's observations in 11 romanzo senza idillio. Saggio sui Promessi Sposi (Torino, 1974), p.62.

21 Lettere, 1, 193-94.

22 Op. cit., p.65.

23 Piemontese, p.109, maintained that Carlo derived his attitudes, ambitions and forma mentis from his time.

24 Cf. Goffis, p. 233.

25 Op. cit., p. 90.

26 M. Sansone, L'opera poctica di Alessandro Manzoni (Milano-Messina, 1947), p.175. Aurelia Accame Bobbio, 11 cristianesimo manzoniano tra storia e poesia (Roma, 1954), p.42, thinks that what attracted Manzoni most in the year 1820 was the desire to understand and express what the fall of the Lombard Kingdom had meant in the history of the Italian people. See also her Alessandro Manzoni. Segno di contraddizione (Roma, 1975), pp.171-72.

27 Gilberto Lonardi, L'esperienza stilistica del Manzoni tragico (Firenze, 1965), p.39.

28 In any discussion of the Adelchi, we must recall Manzoni's own unhappiness with the character of Adelchi: "tutto il carattere in somma è inventato di pianta, e intruso tra i caratteri storici, con un'infelicità, che dal più difficile e dal più malevolo lettore non sarà, certo, cosi vivamente sentita come lo è dall'autore." See Poesie e tragedie, Vol. 1 of Tutte le opere (Milano, 1957), p.551. For the question, see Manzoni's letter to Goethe of 23 January 1822 in Lettere, I, 223.

29 Opere moralie filosofiche, Vol. III of Tutte le opere, p. 508.

30 Cf. M. H. Abrams, "English Romanticism: The Spirit of the Age," in Romanticism Reconstdered: Sclected Papers from the English Institute, ed. Northrop Frye (New York and London, 1963), pp.26-72. The fifth letter in Schiller's On the Aesthetic 
Education of Man is also of interest. John Stuart Mill also occupied himself with the subject, saying that men speculate on the pecularities of their own age and distinguished them from the features of former ages. The Oxford English Dictionary gives the first use of the term "spirit" as occurring with Shelley in 1820.

31 Lettere, 1, 342. This position was, of course, normal in the Conciliatore.

32 See Friedrich Engel-Janosi, Four Studies in French Romantic Historical Writing (Baltimore, 1955), pp.111 and 117.

33 Nouvelle edition (Paris, 1867), p.11, and for the following reference Waverley Or, 'Tis Sixty Years Since (New York, 1964), p.114.

34 Histoire de la conquête d'Angleterre (Paris, 1867), I, 334, also quoted by Cesare De Lollis, Alessandro Manzoni e gli storici liberali francesi della Restaurazione (Bari, 1926), p.33. For a more pessimistic viewpoint on the transience of the generations and their passage into eternal silence, see Benjamin Constant, De la religion (1826), I, 46 and Georges Poulet, Constant par lui-même (Paris, 1968), pp. 28, 29, and, of course, Scott, The Lady of the Lake, Canto III, first stanza.

35 Opere Varie, Vol. III of Opere, a cura di Guido Bezzola (Milano, 1961), p.376.

36 Tutte le opere, IV, 3-4.

37 Cf. Claudio Varese, "'Mélange' e tempo nel Manzoni," in Studi in onore di Luigi Russo (Pisa, 1974), p.237.

38 Lettere, 1, 227.

39 I have been able to consult only the English translation (London, 1822).

40 Romantic Narrative Art (Madison, 1960), pp.180-81.

41 Cf. David Daiches, "Scott's Achievement as a Novelist," in Scott's Mind and Art, ed. A. Norman Jeffares (Edinburgh, 1969), p.51. Naturally the pages of Georg Lukács, The Historical Novel, are fundamental.

42 Introduction to lvamhoc (New York, 1961), p. 26.

43 Daiches, p. 34

44 Tutte le opere, Volume II, Tomo 3, Fermo e Lucia, $3^{\text {a }}$ ed. (Milano, 1964).

45 Manzoni e la guerra contrn il tempo (Padova, 1973), p.40. Cf. Enzo Noè Girardi, "Manzoni e il Seicento," in E.N.G. e Gabriella Spada, Manzoni c il Scicento lombardo (Milano, 1977), pp.11-31.

46 Op. cit., p. 162.

47 The Historical Novel, trans. from the German by Hannah and Stanley Mitchell (Harmondsworth, 1969), p.79.

48 Cf. Niccolò Tommaseo, Il Duca d'Atene, in Due baci c altri racconti, a cura di Carlo Bo (Milano, 1943), p.150: " . . perchè tutti, anco i buoni, vivono la vita dell'età Ioro comecchè possano rinchiudersi in monda cella o spaziare con l'occhio da una ardua e salubre cima, un orizzonte medesimo, una medesim'aria li circonda e li copre."

49 See Marian H. Cusac, Narrative Structure in the Novels of Sir Walter Scott (The Hague - Paris, 1969), p.19. Unlike Scott and novelists of the late 18th century, Manzoni never intervened to see that a scene was worthy of a certain painter; see also Luciano Bottoni, "Scott e Manzoni 1821: tecniche descrittive e funzioni epistemologiche," Lingua e stile, 5 (1970), 409-34, but especially 409-14. Manzoni was termed "a Flemish painter" by both Antonio Cesari and Pietro Giordani; see Giovanni Sforza, "Le prime accoglienze ai Promessi Sposi," in Opere di Alessandro Manzoni (Milano, 1905), Volume II. Parte II, pp. xxvii and xxx, who also gives other instances of comparisons of scenes from the novel with painting.

$50 \mathrm{Cf}$. the comments of Romano Amerio in his edition of the Osservazioni sulla morale cattolica (Milano-Napoli, 1965), 1I, 319-20. 